[Meade, A. (1993). Contestability in the Special Education and Early Childhood Sectors: A Mechanism for Countering Equity? New Zealand Annual Review of Education, 2, 93-106]

\section{Contestability in the Special Education and Early Childhood Sectors: A Mechanism for Countering Equity?}

\section{ANNE MEADE}

$\mathrm{T}$

he reforms in education in New Zealand in the late 1980s were characterised by their concentration on the administrative system (Dale \& Ozga, 1992) whereas other countries had curriculum and assessment changes as well.

I want to explore an administrative measure in this paper - a measure called "contestability". Contestability refers to the principle of "alternative provision". Alternative provisions are being promoted by Market Liberals to give consumers a choice, which they see as highly desirable. The Treasury, in its 1987 Brief to the Incoming Government, stirred up a debate on "voluntary choice versus state direction" (1987, p. 17). The debate has been active ever since.

The 1989 policy statements - by and large - restricted the introduction of contestability to non-educational operations, (such as the supply of stationery to schools), although they indicated that alternative educational provisions would be approved in future years. When the National Party was elected to government in late 1990, it soon became apparent that it would translate Market Liberal philosophy into policies. An "Economic and Social Initiative Statement" was released within weeks, and it clearly indicated a Market Liberal agenda. Choice versus state intervention was a dominating concept, and the debate fostered by The Treasury in 1987 was alive again.

I believe this debate is on-going mostly because the Treasury and the State Services Commission are persistent. The Treasury argues for less state intervention in education because governments curtail
94 Anne Meade

people's "sphere of responsibility" and weaken their "self-steering ability ... to reach optimal solutions through the mass of individual actions pursuing free choice" (Treasury, 1987). A second assumption of Market Liberals is that organisations, including non-commercial educational organisations, maintain efficiency when there is exposure to potential or actual competitors.

By 1992, the Government had become pro-active in actioning the principle of contestability for educational services; that is, it was actively encouraging alternative providers to compete where the Welfare State used to be the sole provider of such services.

In 1992 there were two significant structures in which the contestable provision of educational services was being introduced. These were the Crown agencies which provide support services to teachers, managers and parents: the Special Education Service, providing specialist support and interventions for children with special educational needs, and the Early Childhood Development Unit which is associated with early childhood care and education.

\section{Special Education: Background}

Special education, since the education reforms, has been a shared responsibility. The three main parties are the schools, the Ministry of Education, and the Special Education Service. Schools enrol children with special educational needs, and must ensure that their policies and practices cater adequately for all children regardless of their ability or disability. The Ministry of Education is responsible for ensuring the schools have policies for students with special educational needs in their charters, and has final responsibility for allocating discretionary resources to those children whose needs demonstrate that additional support is warranted. The Special Education Service (SES) has been given the statutory function to "provide advice, guidance and support for the benefit of people under 21 with difficulties in learning and development", (Education Act, 1989). In 1991, 43,600 such students were "on the books" of SES.

By coincidence, not by design, the Education Act 1989 gave the parents of all children, regardless of type or degree of disability, the right to a free enrolment for their child in a state school. It gave parents the choice to use special schools or mainstream schools. Growing numbers of parents have chosen to exercise the right for their child to be integrated into regular classrooms in the intervening years. 
Categorisation procedures and labels have been decreasing in significance as a consequence.

Although all students are now required to enrol at a school, there is no matching entitlement to resources. Generally, students enrolled in special schools or units encounter few difficulties in accessing the resources they need. As more children move to regular settings however, difficulties are being encountered in arranging for the expert staff and additional resources they need to follow them.

Dale (1990) and others have suggested that settlements in education need a balance between entitlements to and provision of education. For families with children with disabilities there has never been a satisfactory settlement in New Zealand. The enrolment clauses in the Education Act, 1989 raised parents' expectations that there would be a better deal. At a time when the Welfare State was in retreat, an expansion occurred in the form of additional children gaining an entitlement to a state education. Some increase in the provision of resources (improved physical access to school buildings and extra aide hours) accompanied the change. However, the provisions have proven inadequate because of double expansion into mainstream schools children who were at home, in hospitals or in IHC facilities are now enrolled, and students who were in special schools are now transferring. I have argued elsewhere (Meade, 1990b, p. 6) that to effect a new balance, "new resources and a re-allocation of resources are needed." I believe Market Liberal economics has stopped such moves. To reduce Government spending, Treasury appears to have been more than happy to retain savings where enrolments in regular education have resulted in closure of unsustainable segregated special schools. As well, proposals by Market Liberals for contestability in special education services have deflected attention away from the imbalance between entitlement and provision, (ibid, p. 8).

\section{Contestability in the Special Education Sector}

Contestability has been hanging in the air for special education for a number of years. The Picot Taskforce (1988), recommended that 60 percent of the funding for special education advisers go into schools' bulk grants:

[Special education advisors] will be employed by those learning institutions who use their services. However, because their services are essential (because of the state's policy on "mainstreaming") and because demand is uneven, there will need to be a mechanism to encourage their continuity of supply. We propose, therefore, that 40 percent of expected costs of services should be funded directly by the state, as a retainer to special education advisers. The balance of the income needed would be generated by advisors earning fees from institutions themselves (Picot, 1988, 7.5.6.).

This was soon diluted. Tomorrow's Schools stated that only

20 per cent will be included in the bulk grant to institutions for use of purchasing specific services, identified by the institution's teachers,

and, later,

The Special Education Service's early childhood advice will be available free of charge to services and families (Before Five, 1989, p. 15).

But, by the time SES was set up, the Labour Government had backed away from making a proportion of the Service's funding contestable for schools. The Lough Committee (1990) again recommended the introduction of contestability in the field of special education for the intervention aspects of special advisers' work (not the assessment aspect). The Government did not implement this recommendation. However the newly-elected National Government re-visited the proposal in reviews conducted prior to its first Budget.

The 1991 Budget stated that the funding the SES currently receives for its free-of-charge work in schools to support the many children who have less severe special educational needs would be transferred to school bulk funds in the cases where Boards of Trustees elected to opt out of the SES. This model assumed a categorisation system which divides children into those with less- and more-severe disabilities.

This banking (opting out) model was spelled out in greater depth in Special Education: Statement of Intent released by Dr Lockwood Smith, Minister of Education in November 1991. Implementation was scheduled for January 1993 to allow time for the categories to be operationally defined and funding formulas to be devised during 1992. By mid-1992 it was apparent that a settlement would not be achieved by the special education policies proposed in the 1991 Statement of 
Intent. In September 1992 the Minister of Education announced a postponement until early 1994.

It was the incorporation of categorisation into the model that attracted most objections. In recent years, additional resources have been provided on the basis of need, not on the basis of classifying children into a disability group. Establishing definitions of what constitutes a more-and less-severe disability is problematic. Furthermore, these were to be applied within the recently-won context of parents having the right to choose where they enrolled their special need child. Parents did not want "the system" to make arbitrary decisions for the support of their child now that they been empowered regarding the education of their child.

Parents, teachers and professionals took advantage of the gap between the policy announcement and its implementation and asked politicians to halt or delay the policy. The Minister of Education agreed to delay. He told the SES Board that he would like to find a new model of contestability which does not incorporate categorisation. Apparently the flaw is seen to be in the model of contestability, not in contestability itself. The most recent move has been to provide a revised definition of contestability. The earlier principle of alternative provision is extended and is explicitly connected to the Treasury notion of "individual actions pursuing free choice," (Treasury, 1987, p. 41).

According to the Special Education Policy Implementation Team Newsletter of September 1992:

Usually contestability is ensured by funding the people who want the services rather than the service provider. It is not the person providing the service who makes the decisions about who should get it, what they should get and how much they should get. People can choose who they want to provide the service and the nature of the service.

This begs the questions, who are the people who can choose who, what and how much? Will it be the child and their family? Or will it be the schools?

If it is the families, how many different providers - in city locations at least - will want access to classrooms, records and teacher time as a result of different families choosing different providers? What sort of administrative load will fall on teachers to know about and inform parents of the options? How will the uneven demand be handled, especially in rural locations?

If it is schools, will it be the teachers or the Board of Trustees who decide? In some schools, this could lead to considerable within-school tension because resources are insufficient. Moreover, teachers and Boards of Trustees may disagree. And what will happen to the 10-20 percent of families who currently self-refer to the SES, often for confidentiality reasons?

The concept of contestability in special education was as problematic at the end of 1992 as it was in 1988. There is every indication that it will not bring about a settlement. Analysis, therefore, needs to focus on the on-going struggle between those who advocate contestability and those who oppose it. Before providing my analysis I wish to examine a different model of contestability - a tendering model.

\section{Early Childhood Care and Education: Background}

A review of entitlements and provisions in the early childhood sector also occurred as part of the reforms in education in the late 1980s. Again, there was an expansion of the Welfare State, against the tide. New Zealand is now regarded as the leader in the Western world for avoiding the pitfalls of targeted provision of services which are so damaging to parent's self-esteem and therefore to parent-child relations. There are now no State restrictions to entitlement, and increased state subsidies (provision) have made services more affordable. The simplification of subsidies to providers into three levels has improved accessibility, as has the changed fees subsidy to low-income families.

The Early Childhood Development Unit (ECDU) was set up in 1989 to handle the operational parts of the early education administrative system. Its principal educational functions are to help set up new early childhood services, to run parent education and support programmes, and to offer advisory support services to staff and managers of early childhood services.

\section{Contestability in the Early Childhood Sector}

Because the concept of contestability had been mooted for the SES, it was included in the early childhood reforms. The policy said that the Early Childhood Development Unit was to charge for its advisory services after two years. The bulk grant to early childhood groups was 
to include "provision for the costs of obtaining advice and support" (Before Five, p. 14). This was in line with the recommendations for the school advisory services. Thus in all cases, advisory services had been cast into the form of a commodity, where institutions could "purchase" advice from a range of alternative providers (competitors). However the Labour Government did not set in motion the actual implementation of contestability for educational services, only for administrative services. In the July 1991 Budget, the newly-elected National Government announced that it had decided the ECDU would also be made "contestable".

The day after the 1991 Budget, an advertisement appeared calling for tenders for the advisory support educational function carried out until then by the ECDU. (The General Manager of the Unit had not even had time to inform staff of the job implications of the euphemistically worded statement in the Budget.) Alternative providers were invited to submit proposals to carry out some or all of the advisory-support work of ECDU. This model of contestability was apparently based on the assumption that potential or actual competition results in efficiency. This line of thinking was evident in the concomitant $\$ 2$ million $50 \%$ cut in the advisory-support budget.

In the event, this process was not carried through in 1991. ECDU held a negotiated contract of service (an "Agreement") with the Ministry of Education which, inter alia, had a committed period. This committed period inhibited such an abrupt and unilateral change being made to the Unit. As well, the industrial relations implications would be major and costly to the tax-payer if a significant portion of the Unit's work were let to alternative providers at short notice. The ECDU took legal advice about a possible breach of contract, and the Government delayed its plan.

The model was re-employed in 1992, and two main providers (and one subsidiary) were selected to provide advisory-support to early childhood services. One main provider was the ECDU, and the other was the Colleges of Education.

At that point the basis of the model shifted from "the principle of alternative provisions" to "the principle of individual choice." A letter was sent to early childhood services by the Ministry of Education saying "Centres will be asked to exercise their choices for the provider to deliver the services which they identify will best meet their needs," (Letter by C. Gibson, 26 June, 1992). Apparently, it was not sufficient to aim for efficiency; "people [were also to] choose who they wanted to provide the service and the nature of the service," (Special Education Policy Implementation Team Newsletter, op. cit.).

The providers were left to "market" their approaches to early childhood services. This caught the Colleges in particular by surprise as their proposal had not been developed in anticipation of this principle being applied. There was a time-lag while new staff were employed, consultation occurred and programmes developed. Meantime, how were centre staff and managers to make an informed choice between the two main providers?

ECDU was more prepared, and quickly produced a newsletter with preliminary information:

The programme we are offering in 1992-93 is:

Consulted agreed work with centres, groups and associa tions carried out in the centres in the way that best meets your needs (an average of 15 hours work with each group throughout the year).

Seminars that give people the opportunity to come together in wider groups, across services, that are on topics that have been requested by groups. (Panui, No. 9, July, 1992)

The next communication from the Ministry of Education to early childhood services brought a new development. The two "options" of this work were separated:

... One of these is in-depth centre based work, the other is seminars.

All centres are free to go to any seminar organised by any provider...

Centres need to choose between the Early Childhood Development

Unit or a College of Education for in-depth centre based work.

(Letter by L. Perris, 13 August, 1992).

Thus, as well as the providers being divided, the actual provision was segmented as well. Given that the money involved amounts to \$2.7 million, such fragmentation hardly seems necessary or efficient in my view. However, an editorial in a journal for independent (private) centres saying that "Contestability is a sham" (Penmann, 1992, p. 4) suggest that others would have liked to see an even greater variety of providers. 
An outside consultant was hired by the Ministry of Education to study the implementation processes of contestability in the early childhood sector (Hobbs, 1992). Hobbs' report indicates that there was perceived to be considerable room for improvement in the areas she had framed questions about: communication, the selection process and tendering time-lines and time-frames. The "Not worked well" replies generally markedly outnumbered the "Worked well" replies. Tucked away in the Executive Summary (p. 2) is a caution by Hobbs against too much further change as it "would only add to the confusion that has been so dysfunctional in the early childhood community over the past ten months". In my view, it was dysfunctional for those who were confused or became caught up in the delays experienced by college providers.

\section{Comments on These Two Case Studies of Contestability}

The rationale for the introduction of contestability provided in Treasury papers (e.g., 1987) rests on two assumptions:

i) competition - real or potential - produces efficiencies in the provision of goods and services, and

ii) contestability reduces state intervention in education which is desirable because governments curtail people's "sphere of responsibility" and "weaken their self-steering ability ... to reach optimal solutions through the mass of individual actions pursuing free choice (Treasury, op. cit., p. 41).

It is probably fair comment to say that the threat of competition resulted in more efficient practices in both the SES and ECDU. For example, in the interim, there was a noticeable improvement in the percentage of hours devoted to direct service provision in the SES; and the ECDU produced a series of resource kits for internal use in running of inservice courses and advising centres, thus reducing the duplication of course development time in the regions. However, as the time for implementation drew closer, other activities counteracted these efficiencies. In the case of SES, considerable time was spent on marketing activities and investigating alternative options for generating income. In the early childhood sector inefficiencies occurred as each College undertook "market research" and duplicated course development work up and down the country. As well, mail-outs to early childhood services and phone calls to clarify the changing ground rules multiplied enormously. The Ministry of Education, ECDU, each college of education and SES (because it won a small proportion of the contestable pool for staff development in centres having children with special educational needs) were all sending circulars to centres. Centres were confused, so they too increased their communications in an attempt to understand what the changing plans for contestability meant in practice. However, the ECDU did their best to provide continuous services throughout, so "their" centres felt less of an impact.

It is debatable whether there is now less state intervention in the provision of early childhood advisory-support and in-service courses. All successful contracting parties are in the state sector (contributing to the independent sector's discontent?), and now the Ministry of Education is involved at two stages (tendering, and centres exercising their choice of provider) involving dialogue with more parties.

The second argument made by the Treasury for contestability, assumes that ECDU and SES did not share some of the responsibility for the nature of advisory services with users, which is not a valid comment. Both had consultative mechanisms to give consumers a say in what should be offered. It also assumes that a mass of individual actions will result in an optimal solution. However, it should be remembered that the individuals (in these cases, schools and early childhood services and the teachers in them who want advisory support) are scattered and relatively few in number in any one location in a small country like New Zealand. The education services they hope to obtain are scarce and specialised. It is not a mass market. Thus, it would appear in theory and practice that specialised, smaller sectors operating in a sparsely-populated country are not likely to gain optimum solutions from market a pproaches to the provision of advisory services in education.

Moreover, the handling of the implementation process, with the hiccoughs and changes of plan or additional steps, was far from efficient. In my view, the confusions indicate that Ministry officials were not committed to contestability and/or lacked expertise in marketing models and their methods of implementation. Hobbs (1992) has a different perspective:

there was clear support from a large majority of respondents for the Ministry of Education to continue as manager of the contestable fund process. The Ministry is thought to be reasonably objective, non- 
aligned and has the expertise to manage contracts. As the Ministry also handles other teacher development projects, this allows for cross-fertilisation of experience in teacher development and curriculum implementation. (Executive Summary, p. 2)

\section{A Conservative Agenda?}

As the economic case for contestability has not been proven, another agenda must exist. I want to argue that the agenda is to weaken the equity gains made by women and, to a lesser extent, Maori in these sectors in the late 1980s. Dale and Ozga (1992) argue that the conservative strand in New Right ideas is not very strong in the New Zealand education reforms (when a comparison is made with the UK education reforms). In my view, the introduction of contestability is an administrative mechanism which contributes to an increasing conservatism, impacting negatively on women and Maori.

The reforms in the early childhood sector did provide gains for women (Meade, 1990a; Wells, 1991) in terms of more affordable, accessible services, more equitable funding, and incentives and opportunities for women to increase their qualifications. There were variable gains for Maori - funding for nga kohanga reo improved well beyond the target recommended in the Government Review of Te Kohanga Reo (1988), and the Early Childhood Development Unit achieved a notable EEO situation with over one third its staff being Maori.

The improvement for women in special education came mostly as a consequence of the clauses in the Education Act 1989 giving all children with special education needs the right to enrol in a state school. Mothers of previously excluded children could exercise a greater range of options once they could share the responsibility for the care and education of these children with schools. This liberating effect has not gone far enough apparently (if the 1992 petition of the NZCCS (formerly the NZ Crippled Children's Society) for more teacher aide hours is any indication). As well, primary teachers and teacher aides (predominantly women) have been able to extend their skills to this group of students because of the in-service courses and classroom-based professional development offered as more children with disability are taught in mainstream classrooms. Advantages to Maori in special education provisions have been noted as a consequence of the multidisciplinary (holistic) team approach adopted by the SES once all specialists were under one management structure, and the SES policies for services to Maori based on Maori development principles.

Because of the concern about contestability being introduced for the Special Education Service in 1993, teachers, parents and SES staff have been deflected from seeking improvements to the amount of and system for allocating discretionary resources - the change needed to make some progress in special education. Teachers have had less time, energy, incentive and opportunity to enhance their professional skills in managing children with special needs in regular classrooms. Mothers are still being asked to provide aid in the classroom, which fits with the conservative theme of "a woman's place is in the home". Maori protested about the proposed model of contestability "because the categorisation of children could divide whanau members and fragment the resources of support that would be available. As well, Maori are to be found in disproportionate numbers in the proposed category of students with less severe learning difficulties. If schools opted out of the SES, a disproportionate number of Maori would have to lobby each school (with very mixed outcomes) for the specialist help for their mokopuna which comes free, as of right, from the SES at present.

In the early childhood sector, women have experienced a theft of their intellectuality (Meade and Kennedy, 1992). Not only has there been a loss of opportunities for early childhood teachers to take inservice courses and to gain professional development via in-depth centre-based advisory support while the contestability models have been debated and implementation fumbled, but the Government has weakened the qualification requirements for staff in charge of an early childhood service (Meade and Dalli, 1992). By putting back the date from 1994 to 2000 for the person in charge to have a Diploma of Teaching (or its equivalent), there is less incentive for teachers in the sector to upgrade their qualifications. This contributes to the continuation of early childhood teachers being perceived to be low status, manual workers. For Maori, the loss has been in positions in the ECDU-just as Maori women were improving their career opportunities in early childhood, job losses were forced onto an employer with a better-than-average EEO record for Maori. 


\section{Conclusion}

Michael Apple (1989), describing sites of struggle (as exemplified in the case studies in this chapter), says that conflict may be intense where dominant groups try to restore or expand their prerogative over groups who are more "people oriented". It would seem that the dominant groups disliked the expansion to the Welfare State achieved in these two sectors in the 1989 reforms. In 1991-2 these dominant groups found an administrative mechanism to assist them to restore the power (im)balance that existed in the special education and early childhood sectors prior to the reforms. It is women and Maori who have borne the brunt of these moves. In the early childhood sector the resistance was minimal. However, the struggle against contestability in the special education sector was intense and widespread in 1992, and it is by no means over.

\section{Note}

1. See, for example, submissions made to the Select Committee on Maori Education, 1992

\section{References}

Apple, M. "Re-defining Equality: Authoritarian Popularism and the Conservative Restoration," Teachers' College Record. Vol. 90 (2), 1988, pp. 167-184.

Dale, R. "The Limits and Possibilities of Education", Access, Vol. 9 (1), 1990.

Dale, R. \& Ozga, Jenny "The 1980s Education Reforms in New Zealand and England and Wales: Two hemispheres, both "New Right"?" in Lingard, R., Knight, J. \& Porter, P. (eds) Reforming Education in Hard Times. London: Falmer, 1992.

Government Review of Te Kohanga Reo. Wellington: Department of Maori Affairs, 1988.

Economic and Social Initiative - December 1990. Statements to the House of Representatives: Hons J. Bolger, Ruth Richardson, W. F. Birch. Wellington: GP Print, 1990.

Hobbs, Margaret "Review of the Management of the Early Childhood Contestability Fund", September 1992. (This report was released under the Official Information Act.)

Lange, D. Before Five: Early childhood care and education in New Zealand. Wellington: Department of Education, 1989.

\section{Anne Meade}

Meade, Anne "Women and Children Gain A Foot in the Door". Women's Studies Journal, Vol. 6 (1/2), 1990a.

Meade, Anne "Working Towards the Future". Herbison lecture delivered at the NZARE conference, Auckland, December 1990b.

Meade, Anne and Kennedy, Pamela "Early Childhood Training and Qualifications, Before and Beyond 2000: Double gain or theft of our intellectuality?" Proceedings of Qualifications in the 21st Century International Conference, Wellington, January 1992.

Meade, Anne \& Dalli, Carmen "Review of the Early Childhood Sector" in Manson, H. (ed) New Zealand Annual Review of Education 1:1991. Wellington: Victoria University, 1992.

Panui to Early Childhood, No. 9, ECDU, July 1992.

Today's Schools (the Lough Report). Wellington: GP Print, 1990.

Tomorrow's Schools: The reform of education administration in New Zealand. Wellington: Government Printer, 1988.

Treasury, The Government Management: Brief to the Incoming Government, Vol. II, Education Issues. Wellington: The Treasury, 1987.

\section{The author}

Anne Meade is the Director of the New Zealand Council for Educational Research. Until 1992 she was a Senior Lecturer in Education at Victoria University of Wellington and taught courses on early childhood care and education at undergraduate and postgraduate levels. In 1988, she convened the Working Group on Early Childhood Care and Education which prepared Education to be More. 